\title{
Summary on Characters and Features of College English Teaching in China*
}

\author{
Zhang Jian-jia \\ Southwest University, Chongqing, China
}

\begin{abstract}
This paper aims to discuss the current situation of college English teaching and middle school English teaching in China, especially the severe state of college English teaching. College English teaching can be divided into English teaching for English majors and non-English majors. Their teaching value orientation and teaching goals are different, because China is a vast country with large areas with conditions of some developing and some undeveloped, and therefore English teaching requirements vary from place to place. The paper advocates that English teaching in China, especially college English teaching, should meet the needs of English language so as to cultivate students' real application ability of English.
\end{abstract}

Keywords: Chinese college English course, English teaching, summary

\section{Introduction}

Nowadays, college English teaching in China occupies a very important part in all colleges and universities. Near all colleges and universities set up college English course. However, the teaching for the course almost is taken the similar methods as the spoon-fed and force infusion in the process of class teaching. The result for this kind of teaching leads to "time-waste and poor effect," as called by Chinese former vice premier Li Lanqing, who was in charge of China's educational affairs. So, college English teaching gets a bad reputation for the type of teaching. This traditional and preponderating teaching style makes it difficult for teachers to teach and students to understand, especially boring in attending the class teaching not only by students but also by teachers. Fortunately, many researchers began to realize the terrible situation and strive to solve the problem. For instance, Professor Wang Shouren (Nanjing University) discussed various issues in College English teaching, such as the status of English teaching in China's educational system, students' ability to use the English language, the application of computer technology, the link between language learning and academic studies, and the impact of College English Test Band 4 and Band 6 on classroom teaching (Wang, 2006, p. 3). Yan and $\mathrm{Wu}$ (2002) pointed out four orientation for the teaching: (a) application ability; (b) teaching system among primary school, middle school, and university; (c) change of the teaching mode and evaluation method; and (d) graded teaching. In a word, many scholars are probing into the teaching issue in one way or another. As we all know, teaching is a kind of special art. English teaching, especially college English teaching, is firstly a sort of language teaching, and therefore any language teaching and learning cannot go without following its rules and orientation, in order to make college English teaching in China better. First of

\footnotetext{
* Science Research Item: The Survey and Analysis of Value Orientation in Chinese University English Teaching (Foreign Language Studies College of Xiangnan University), Hunan Philosophy Social Science (2011/10/11WLH49), China. Zhang Jian-jia, Ph.D. candidate, Faculty of Education, Southwest University.
} 
all, an analysis of characters and connotation of college English teaching must be made.

\section{Characters of College English Teaching in China}

In 2004, Ministry of Education of the People's Republic of China issued College English Curriculum Requirements (for trial) as the guidance for non-English major undergraduates' English teaching in higher education, which clearly set the college English teaching character: College English teaching is one of the organic components in higher education; college English course is a necessary basic one for undergraduates. College English teaching is a kind of teaching system based on English language knowledge and applied skills, learning strategy, and cross-cultural communication, guided by foreign language teaching theory and multi-teaching mode and teaching means. However, in China, college English course is actually designed as a scientific system, not a language system, which makes teaching behavior not easy to control. The strict and normative English language knowledge, use ability, learning tactics, and culture communication become vague because the design is not comply to foreign language teaching theory. If the course is designed according to language rules and taught by ways of adopting flexible teaching methods, adhering to the rich teaching effects, abiding by the requirements value principle, and adopting the practical and effective teaching value orientation, then students will acquire the language more easily. Only in this way can college English teaching in China meet with the requirements of College English Curriculum Requirements (for trial). What is more, the ultimate goal of language teaching can be reached. Because the goal of college English teaching is to cultivate students with all-round English application ability, especially listening and speaking abilities, making them apply English effectively by way of oral and written information exchange in their daily work and social communication in the later years. Meanwhile, it aims to strengthen students' autonomous learning ability and improve their overall culture quality, so as to suit China's economic development and international exchange.

\section{Similarities and Differences Between College English Teaching and Middle School English Teaching}

There are different requirements between college English teaching and middle school English teaching in China although they are the same as English language teaching. As for the middle school English teaching, it includes two parts, such as primary and advanced levels but with different emphasis. The teaching goal and requirement of the primary level mainly focus on understanding basic English language knowledge, respecting and holding exotic culture consciousness, and building English learning confidence and tactics. However, because of China's large area and different school bases, the teaching goal and teaching requirements can be generally divided into two parts: lower level and upper level, and quite often in reality more detailed level requirements are raised from English listening, speaking, reading, and writing, but none of the levels raises a claim for translation ability, in which we think can represent mastery of more higher level of English language ability. The said requirements are also basically limited to textbook, familiar life subject matter, and simple English exchange and communication between teachers and students inside and outside class. Their teaching goal is just form motivation and cultivation of English learning, form of English language sense, form of primary English application ability in listening, speaking, reading, and writing skills, promotion of application of English communication ability, and strengthening the understanding of English culture. The courses design is similar between lower and advanced levels. There are 5-6 hours of class in each week of every semester for the three-year study in junior and senior high school respectively. Teaching contents on the whole focus on English pronunciation, grammar, and words, and what is more, teaching style often just overweight the 
understanding and memory of words, phrases, and sentences. Although some specific teaching requirements are required in the real separate teaching programs, e.g., 8th grade in higher level and 6th grade in lower level, and the teaching evaluation is set for some more concrete teaching reference ideas, yet all of the teaching requirements stress that in the process of teaching, students must be in the dominant position and teachers in directive function, foreign language teaching must be in a maximized use, mother tongue communication must be minimized used, and these teaching requirements are to actively cultivate students' interest of learning English language, to highlight actual application ability of English language, to develop English language learning tactics and methods, and finally to establish quality education concept, and what is more, in all teaching process, one must make most of visual aids and modern teaching means, carefully deal with the relationship between the English language and culture, abide by English language teaching regularity, etc.. But, in actual teaching activities, no matter how it is, primary or advanced, the basic evaluation tendency to English teaching in middle school is only according to the criteria that the lower or higher achievements students made. Teaching is severely influenced by the National Entrance Examination and badly neglects the real teaching value and its orientation. Taking into consideration of China's fast development in middle and eastern parts and the slow development in northwest part and some other large and underdeveloped areas, the real big difference in higher education exists inevitably. And college phase English teaching requirements are divided into general, upper, and higher levels in College English Curriculum Requirements (for trail) (Ministry of Education of the People's Republic of China, 2004):

The three English teaching requirements include the use ability of English language knowledge, application skills and learning tactics, and cross-cultural communication. These requirements can be the representative of guidance teaching concept for college English teaching in either qualitatively and quantitatively. That is to say, all requirements stress on the cultivation of students' English listening, speaking, reading, writing, and translating ability. The general requirement is the basic one reached by non-English major undergraduate students in higher education. All colleges and universities according to the actual situation should set the teaching goal and create conditions to encourage students based on their own learning circumstance and adjust their own learning goal by moving forward upper and higher requirement.

Therefore, it can be seen that college English teaching and middle school English teaching on one hand share the same basic requirements as English language knowledge, English learning tactics, and cross-cultural communication. On the other hand, college English teaching aims to get more higher promotion in English language application ability that can be represented by translation ability, in which one's English language proficiency can be shown, such as vocabulary, i.e., 800 words and 200 phrases in primary English level and 1,200 words and more phrases in advanced level. In college, the general level requires students to acquire 4,500 words and 700 phrases, upper level 5,500 words and 1,200 phrases, and higher level 6,500 words and 1,700 phrases. In reading aspect, in middle school, the new words rate in the first level in reading is no more than $2 \%$ of what they have learned, $40-50$ words per minute; the new words rate in the second level is no more than $3 \%$ of some familiar material, 50-70 words per minute. Reading in college requires long passages, lower level 100 words per minute, fast reading with longer passage with 120 words per minute, by dictionary reach the goal to read original English books, newspapers, and magazines, and more easily to read one's own professional all-around documents. In translation, no requirements for middle school students, while in college, there are more requirements for mutual interpretation from Chinese to English and vice versa, from 250 words to 350-450 words per hour, no serious language mistakes, smooth reading, and contents can be expressed correctly. College courses are designed in multiple and complicated ways, including listening, speaking, 
reading, writing, and translating, not only fully considering students' different English proficiency level, but also guaranteeing their learning level improvement. Meanwhile, personal teaching and mode of execution are carried out, and special features of major characters must be met with. Different course designs are a great challenge for teaching. In teaching mode, many colleges and universities as some middle schools in a good condition make most of modern information and network technology, and they work hard to take some active situation in class teaching. Of course, college teaching is in a tendency of more culture, interest, personality, and knowledge. However, generally speaking, the college role of the English teacher-domination and students-subjectivity is not effectively exerted, instead remains the teaching mode of infusion and spoon-feeding; teaching value basically stays in exam-orientated teaching, intellectual acquirement, and instrumental learning, and teaching evaluation stresses formative assessment, neglects the function of process assessment. Therefore, there is a difference between middle school English teaching and college English teaching. The difference between them is bound to form an attack for teaching mode, and the shift of teaching mode means some change of teaching means, teaching concept, and teaching value orientation. To some extent, to change the long-established teaching habit is equal to a revolution without battle smoke, and a very great challenge for college teachers' individual quality.

\section{Similarities and Differences Between College English Teaching for English Majors and Non-English Majors}

College English teaching for English majors and non-English majors get their own features although they are the same as all are English teaching for students in colleges and universities, which can be regarded as an isomerism that English teaching in class is in different ways. Both kinds of English teaching are the same. First of all, the students, as teaching objects, are with different English level. Teaching involves special relationship between teachers and students that based on spreading human being knowledge, cultivating learning ability, creating qualified social talents, and forming a relative concentration of teaching and learning and a very special relationship between teachers and students. The relationship between teachers and students means a lot. As for the teacher, regardless of teaching objects' actual situation, without any kind of soul communication and convulsion with the viewers at sub-stage, the teacher will be act as a soloist in the stage like a self-director and self-performer and, therefore, poor teaching achievement will be reached. As for the learner, if the basis of learning is very weak, just like appreciation of un-matching performance at stage with skills and abilities, then any so-called wonderful performance cannot reach an active result. The English knowledge and proficiency of English major students with good English basis are higher than non-English majors, for accordingly the receptivity of the teaching benefit rate for English majors is a little bit higher. Secondly, the application of teaching mode is different. As all knows, the various teaching modes are bound to be differences of teaching efficiency. At present, the college English teaching mode appears a splendid legacy, yet the essential character of profession and non-profession determines the prominent differences in English teaching among degree of difficulty of textbook content, teaching time for long or short, application of teaching means, interactive rate of teaching process, and comprehensive aspects of teaching evaluation. It must be admitted that major English teaching presents clearly that the students can at full blast learn English language, also their fundamental and main task in college period, which can fully demonstrate the essential meaning of English teaching with professional feature. Non-English major students on one hand learn English and on the other hand learn other subjects except English. Thirdly, the difference of teaching goal of realization scope varies from English majors 
to non-English majors. No matter how English major or non-English major teaching it is, the common goal is to improve college students' English comprehensive application ability. But for the teaching goal, when set, it must meet the needs of actual demand, only finally reach the destination. If mention about the teaching goal separate from English majors and non-English majors, it is easy to fall into the putschism mire.

\section{The Essential Connotation of College English Teaching in China}

College English teaching is essentially the humanistic spirit teaching based on English as native language. Humanistic spirit is to "seek for human value" (Wang, 2012, p. 8), which advocates the all-round value realization of people's health and physics in the real life. Therefore, humanistic spirit is the soul of education and teaching. That is to say, to master the marrow of humanistic spirit in language teaching is to get the value core of language teaching, i.e., internalization in the process of "teaching" by teacher and "learning" by students. This internalization is certainly to be an important factor for the promotion of teaching efficiency and also must be the value orientation in college English teaching. Nowadays, in China, college English teaching process is divided into three ways to demonstrate its essence, for instance, teaching interaction, aesthetic consciousness, and translation reappearance.

Teaching interaction is an embodiment in the process of teaching while teachers and students are equal with harmonious relation and interaction between teachers' guidance and students' subject position. The equal and harmonious relation between teachers and students can improve the interaction ratio in the process of teaching and learning, and therefore, the generative teaching can be reached very naturally in which the ideology notion, cognitive consciousness, and value orientation between students and teachers can collide mutually and spark some wisdom from doing so. Teachers' teaching and students' learning is an interactive process, in which students' subjective initiative can actively be exerted in the following aspects: listening to teaching, acquiring knowledge, and taking positive communication, while teachers' guidance for students therefore can be the teaching lead, behavior guide, and knowledge generation. That is to say, the teaching interaction can both pay highly respect for the personality of the teacher and the student, because their integration of both self-devotion and participation makes this sort of teaching be more vivid, more emotional resonance, and more active atmosphere. All of these is beneficial to form a harmonious relationship of interdependence, mutual cooperation, and development between teachers and students, to develop teacher's leading and demonstration role, and to dig out students' initiative and creative learning. By doing so, a solid foundation to poster new-type talents with creative spirit and ability can be laid.

Teaching is a kind of art. Any teaching is regarded as one part of art and aesthetics consciousness lies in the process of our life. The aesthetics consciousness of college English teaching is around us. For example, the English phonetics rhythmic beauty, lexical interpretive beauty, cultural connotation beauty, textbook knowledge beauty, and grammar preciseness beauty all exist in the entia of both outer beauty and inner beauty. Phonetics can be the beginning of English teaching, the pronunciation harmony and symmetry of English consonants and vowels adds the learning interest, the various forms of English form with polysemy generally originate from famous literature works, bible story, mythology legendary, gossip column, custom convention, sports and amusement, historical events, etc.. English sentences are echoed with strong, weak, fast, and slow rhythm; English intonation is melodious, English sound is metrical, and English flow is with flowing rhythm. All of them are kind of enjoyment of beauty vividly and incisively. It is a kind of teaching art promotion by catching these elements to carry out teaching. 
Translation as an important aspect and means of foreign language teaching has been stressed in various ways. Strictly speaking, any foreign language (including English) teaching cannot separate from translation as an easy tool to understand and master the foreign language effectively. Translation itself is one language transferred into another language. Therefore, translation is applied into teaching especially. English teaching becomes a very natural teaching method. The problem lies in how to effectively make full use of the translation function to promote college English teaching. For example, application of language must be expressed correctly after correct understanding and translation must be done correctly after correct understanding, so translation is used in college English teaching in China as a feasible and effective means. In the process of college English teaching, translation is added, which can be beneficial to foster students' ability to deeply recognize English language and strengthen the comprehensive application ability of English knowledge.

\section{Conclusion}

In a word, the fundamental goal of any teaching is to cultivate people, i.e., to foster fully-developed individuals. The experienced English teaching expert, professor Xu Guozhang, once said:

I never teach my students based on understanding several English sentences or one ability as the teaching goal. I taught my students how to be a man. English education is used as to learn culture, to understand the world, foster their thinking rather than English language teaching. No language teaching can be separated from this parenchymalia of language and culture. (Wang, 1991, pp. 45-46)

Only in this way can educators get some correct teaching value orientation, because they have been misunderstanding the teaching value orientation by relying on the attention to the language tool and neglect of humanities in language teaching, which makes college English teaching in China a bad teaching result for so many years.

\section{References}

Cai, J. G. (2007). China college English teaching feature and countermeasure research in the transition period. Foreign Language Research, 1, 45-47.

Cai, J. G. (2010). The factor analysis of control China college English teaching orientation transition. Foreign Language Research, 2, 38-43.

Dudley-Evans, T., \& St John, M. J. (1998). Developments in English for specific purpose. Cambridge: Cambridge University Press.

Jiang, H. (2014). College English teaching reform. Education and Occupation, 35, 146-147.

Kong, Y. F. (2004). The reform and knowing of college English teaching. Meitan Higher Education, 2, 89-90.

Liu, R. Q. (1996). English teaching of the century. Foreign Language Teaching and Research, 2, 34-36.

Ministry of Education of the People's Republic of China. (2004). College English curriculum requirements (for trial). Beijing: Tsinghua University Press.

Nie, S. M. (2011). Ethics construction of college English teaching reform in China. China Power Education, 28, 186-188.

Tian, Y. Z. (2014). Research into subject orientation and teacher transition of college English teaching. Shangxi Education, 3.

Wang, S. R. (2006). Based on the improvement the quality of higher education in the country, imper the reform of college English teaching. Journal of Foreign Language World, 5, 3.

Wang, S. R. (2011). Current situation survey of college English teaching and the reform and its development path in China. China Foreign Language, 9, 25-29.

Wang, Z. L. (1991). On language by Xu Guozhang. Beijing: Foreign Language and Teaching Press.

Wang, Z. L. (1997). Translation: Thinking and practice. Beijing: Foreign Language Teaching and Research Press.

Wang, Z. L. (2012). Cultivation of humanistic spirit-The essence of college English education. Retrieved from http://www.baidu.title.com 
Xie, M. B. (2014). Deep research into college English teaching in China. Journal of Mudangjiang College of Education, 9, 86-87. Yan, Z. J., \& Wu, S. X. (2002). The reform of college English Teaching is imperative. Journal of China Higher Education, 6, 8-9. Zhang, J. J. (2014). Current teacher professionalization issue and its development paths in Chinese higher education. US-China Education Review B, 4(8), 529-535.

Zhang, Q., \& Chen, J. (2013). Several thinking of college English teaching reform. Xueyuan, 30, 1-4. 